\title{
Teaching Creativity in Engineering Courses
}

\author{
Shanna R.Daly, Erika A. Mosyjowski, and Colleen M. Seifert \\ University of Michigan
}

\begin{abstract}
Background The ability to engage in a creative process to solve a problem or to design a novel artifact is essential to engineering as a profession. Research indicates a need for curricula that enhance students' creative skills in engineering.
\end{abstract}

Purpose Our purpose was to document current practices in engineering pedagogy with regard to opportunities for students' creative growth by examining learning goals, instructional methods, and assessments focused on cognitive creative skills.

Design/Method We conducted a critical case study of engineering pedagogy at a single university with seven engineering courses where instructors stated the goal of fostering creativity. Data included instructor and student interviews, student surveys, and course materials. For qualitative analysis, we used frameworks by Treffinger, Young, Selby, and Shepardson and by Wiggins and McTighe.

Results One aspect of creativity, convergent thinking (including analysis and evaluation), was well represented in the engineering courses in our case study. However, instruction on generating ideas and openness to exploring ideas was less often evident. For many of the creative skills, especially those related to divergent thinking and idea exploration, assessments were lacking.

Conclusions An analysis of pedagogy focused on goals, instruction, and assessments in the engineering curriculum revealed opportunities for growth in students' creative skill development. Designing assessments that motivate students to improve their creative skills and to become more aware of their own creative process is a key need in engineering pedagogy.

Keywords creativity; design; engineering pedagogy

\section{Introduction}

The ability to engage in a creative process to define or solve a problem or design a novel artifact is essential to engineering as a profession, and especially to future engineers (Prahalad \& Ramaswamy, 2003). Numerous reports emphasize the need to support engineering students in their ability to think creatively (Felder, Woods, Stice, \& Rugarcia, 2000; National Academy of Engineering, 2004; Sheppard, Macatangay, Colby, \& Sullivan, 2009). Standard designs are appropriate and necessary in many situations, but their outcomes result in maintaining the status quo (Howard, Culley, \& Dekonick, 2008). Many variables affect solution success or failure, but individual or team creative thinking within the environment is a key source of innovative ideas (Cropley, 2006; Harvard Business School Press, 2003; Soosay \& Hyland, 2004). 
The dependence of engineering progress on creativity is evident in the design focus of many engineering programs. Through creative design, engineers are able to innovate in ways that improve our quality of life and the state of the world (Amabile, 1996; Charyton \& Merrill, 2009; Howard et al., 2008; Mumford \& Gustafson, 1988). Innovation requires the ability to generate novel and useful concepts, discover problems, identify design opportunities, and reconcile contradictions (e.g., Altshuller, 1984; Amabile, 1996; Cropley, 2006; Nickerson, 1999; Sternberg, 1998; Torrance, 1962; Treffinger, Young, Selby, \& Shepardson, 2002).

Felder (1987) stated, "It would seem to be our responsibility to produce some creative engineers - or at least not to extinguish the creative spark in our students" (p. 222). Yet a study by Kazerounian and Foley (2007) found that engineering students felt their instructors did not value creativity, while the instructors reported that they did value it, but found it lacking in their students. The study also concluded that, across fields, engineering has the most room for improvement in supporting creative skill development. In engineering, the word "creativity" may evoke discomfort because it seems subjective and ambiguous. As a result, engineering students may not feel risk taking and creative skills are a valued part of their education.

The goal of our work was to document how engineering courses currently incorporate pedagogy for students' creative skills by examining learning goals, instructional methods, and assessments focused on cognitive creative skills. We used a critical case study approach and focused on a single university (Creswell, 1994; Flyvbjerg, 2001; 2006; Patton, 1990). Interviews with instructors and students, student surveys, and course documents were collected from seven engineering courses at a major Midwestern university's engineering college. Five of these courses were design oriented; the others were a laboratory course and a technical application course. We examined the pedagogy in these courses to find how they fostered creativity, the extent to which current course practices took advantage of known creative techniques, and where there might be opportunities for further development of creative pedagogy within engineering courses.

\section{Background and Theoretical Foundation}

\section{Defining Creativity}

Creativity has been described as a type of novel thinking, where people redefine problems, see gaps in knowledge, generate ideas, analyze ideas, and take reasonable risks in idea development (Gardner, 1993; Sternberg et al., 1999; Sternberg, 2001; Torrance, 1974; Treffinger, Isaksen, \& Dorval, 2000; Weisberg, 1986). Creative thinking has also been defined as the ability to combine and connect ideas in new ways (such as across concepts and fields, among existing projects, ideas, or experiences; Finke, Ward, \& Smith, 1992). One of the most widely accepted definitions of a creative outcome is that it is both novel and useful (Amabile, 1996). In the field of engineering, definitions of creativity are similar (Besemer \& O'Quinn, 1987; Cropley, 2006; Larson, Thomas, \& Leviness, 1999; Nickerson, 1999; Weisberg, 1986, 1999) and emphasize the need to meet functional requirements in a novel way by using the phrase "functional creativity" (Cropley \& Cropley, 2005, p. 171)

While some engineers believe they are not creative people (Kazerounian \& Foley, 2007), this belief does not mean that they cannot be taught to act creatively (Scott, Leritz, \& Mumford, 2004). Creativity is not an attribute or ability that one either has or does not have (Kirton, 2003); rather, all individuals are capable of exhibiting it in different ways, at different levels, and in differing times and circumstances (Cropley, 2001; Rhodes, 1961; Sternberg 
\& Lubart, 1995; Treffinger et al., 2002). Students' creative skills can be developed and fostered, just as practice in any specialized domain can lead to improvements in skills (Ericsson, Krampe, \& Tesch-Römer, 1993). A university course can improve students' creative skills by aligning course content, instruction, assessments, and the environment towards creativityfocused learning goals.

Theories and studies of creativity provide insight on how courses can affect the development of students' creative skills. Some models of creativity emphasize environmental conditions (Dewulf \& Baillie, 1999; Rhodes, 1961; Treffinger et al., 2002; Sternberg \& Lubart, 1995 ) or the interaction of the person and situation (Woodman \& Schoenfeldt, 1990) in the production of creative outcomes. A meta-analysis of 70 studies concluded that successful training programs involved careful instruction focused on the cognitive processes involved in creativity (Scott et al., 2004). Across studies, training and practice of specific cognitive skills led to increased creative outcomes. While a wide variety of potential factors, including social and environmental contexts, were included in the meta-analysis, training on cognitive skills was found to be the critical active ingredient in improvements on students' creativity assessment scores. Scott and colleagues concluded that a focus on cognitive skills for improving creativity is the most effective.

Cognitive processes in creativity are defined as the thinking patterns, traits, and mechanisms that guide and direct creative tasks (Fink, Ward, \& Smith, 1992). Mumford, Mobley, Uhlman, Reiter-Palmon, and Doares's (1991) model also focuses on thinking patterns through specific stages in a creative process, including problem finding, information gathering, information organization, conceptual combination, idea generation, idea evaluation, implementation planning, and solution monitoring. Treffinger et al. (2002) focus on the cognitive operations that underlie the creative process as a whole. This framework synthesizes over 100 studies on creativity (Amabile, 1983; Getzels \& Csikszentmihalyi, 1976; Csikszentmihalyi, 1996; Gardner, 1993; Guilford, 1967; Rhodes, 1961; Torrance, 1962; Sternberg, 2000).

Treffinger et al.'s (2002) framework consists of four primary categories:

Generating Ideas - also referred to as divergent thinking (e.g., Guilford, 1967; Runco, 1991; Wallach, 1970)

Digging Deeper into Ideas - known as convergent thinking (e.g., Guilford, 1967; Finke et al., 1992)

Openness and Courage to Explore Ideas - involves specific personal characteristics (e.g., Rhodes, 1961)

Listening to One's Inner Voice - also known as reflection or metacognition (e.g., Flavell, 1979; Schön, 1993)

By breaking down creativity into its cognitive components, Treffinger et al. resolve some of the ambiguity in defining creativity and provide a more practical understanding of creativity and the ways it can be taught and assessed. Specific categories and indicators of creativity from this framework are discussed in the Methods section.

\section{Creativity Pedagogy in Engineering}

While some university courses provide explicit creativity instruction (Bull, Montgomery, \& Baloche, 1995), few are situated in the engineering context (Charyton \& Merrill, 2009; Dewulf \& Baillie, 1999; Kazerounian \& Foley, 2007; Stouffer, Russel, \& Oliva, 2004). 
A common instructional approach in engineering education is open-ended projects, where the target product is not defined in order to allow creative opportunities. Projects often involve real-world problems with actual stakeholders, and students work in teams to generate solutions (Dewulf \& Baillie, 1999; Stouffer et al., 2004). The instructors may also allow students to select their own project topics. Students sometimes select project topics by investigating personal challenges (e.g., Baillie \& Walker, 1998). Instructors may provide tools to guide students, such as methods to better understand potential users of designed products (e.g., Antonucci, 2011) and idea templates with guidelines to help students consider important aspects of a problem (e.g., Dewulf \& Baillie, 1999). Because open-ended projects have multiple possible solutions, they provide students with the opportunity to generate creative ideas.

One argument in favor of open-ended projects is that students will reflect on their own creative processes as they work through a project, and thereby see ways to improve their creativity (Baillie \& Walker, 1998; Ishii, Suzuki, Fujiyoshi, Fujii, \& Kozawa, 2006; Jablokow, 2001). The aim is to support students' metacognitive skills (reflection on one's thought processes), a recognized method to support deeper learning (Bransford, Brown, \& Cocking, 1999; Brown, 1987; Chi, Bassok, Lewis, Reimann, \& Glaser, 1989; Chi, de Leeuw, Chiu, \& LaVancher, 1994; Schön, 1993). However, some studies suggest that in practice, engineering courses rarely teach directed metacognitive activities related to creativity (Baillie \& Walker, 1998; Ishii et al., 2006; Jablokow, 2001).

The learning environment within a course has also been shown to affect the creativity of student outcomes. Studies have shown that when risk taking is supported in the classroom, students' creativity increases (Sternberg \& Williams, 1996; Thousand, Villa, \& Nevin, 1994; Wilde, 1993). Other classes have supplied structures to guide students, such as assigning the task of generating three different solutions and requiring interaction with other students, in order to encourage and promote creativity (Baillie \& Walker, 1998; Dewulf \& Baillie, 1999). While some efforts are underway to implement these methods in traditional engineering courses, in the academy, change is always slow, and as a discipline, engineering is particularly conservative.

Many engineering programs face inherent challenges in teaching creativity due to a lack of instructional materials in the engineering context, limited time within demanding curricula, and lack of instructor knowledge on how to support students in developing these skills (Felder, 1987; Grasso, Brown Burkins, Helble, \& Martinelli, 2008; Kazerounian \& Foley, 2007; Klukken, Parsons, \& Colubus, 1997; Pappas \& Pappas, 2003; Richards, 1998; Tolbert \& Daly, 2013). Nonetheless, studies have shown general creative skills can be improved with cognitive training (Scott, Leritz, \& Mumford, 2004). Within the context of engineering, several studies have shown increased student performance on specific tasks related to creativity. For example, Cropley and Cropley (2000) found that engineering undergraduates who received feedback after taking a creativity assessment had more creative outcomes on a machine development task compared with students who did not participate in the feedback sessions. Chen, Jiang, and Hsu (2005) researched the effect of a three-course sequence on students' divergent thinking skills and found significant improvement as measured by the Torrance tests of creative thinking (Torrance, 1974). In a study of the effect of a projectbased course on engineering students' creativity, Seng (2000) found students made significant gains on cognitive abilities as measured by discovering concept relationships and flexibility of thinking. These studies suggest that opportunities for creative practice may improve students' creativity in engineering contexts. 


\section{Research Design}

\section{Research Goal}

The goal of our work was to document how engineering pedagogy currently incorporates pedagogy for growth of students' creative skills by examining learning goals, instructional methods, and assessments focused on cognitive creative skills. The scope of the study included instructors' planned pedagogical approaches and their implementation in classes, but did not involve assessing the creative outcomes for students. Examining these elements allowed us to consider how the course design provided opportunities for students' creative development.

\section{Case Study Methodology}

A case study is an in-depth examination of a distinct instance of a class of phenomena, such as an event, an individual, a group, an activity, or a community (Abercrombie, Hill, Turner, \& Erofeev, 1984; Shepard \& Greene, 2003). Our unit of analysis was engineering pedagogy at a single university. To investigate our research question, we chose a critical case study approach; thus we selected courses with strategic relevance to creativity in engineering at one university (Creswell, 1994; Flyvbjerg, 2001, 2006; Patton, 2001). The critical case approach is a qualitative approach that has an interpretivist epistemological perspective. This perspective recognizes that the outcomes depend on the context, and the context is integrated in the analysis of findings (Creswell, 1994; Patton, 2001; van Note Chism, Douglas, \& Hilson, 2008). The goal of the approach is to gather data that facilitate logical deductions rather than generalizations.

Case and Light (2011) highlighted case study methodology as a research approach that can increase knowledge in engineering education, but warned that a common misunderstanding is that the small sample size means the research lacks significant value. The value of case study research is in the detailed, concrete, and practical data situated within a particular context (Flybjerg, 2001). Case and Light (2011) also emphasized that case study methods are particularly appropriate for studies related to "specific application of initiatives or innovations to improve or enhance learning and teaching” (p. 191). Rather than proving the effectiveness of any particular instructional method, the case study method allows the careful examination of the use of pedagogy within a particular course along with the overall course culture. In the present study, using the case methodology allowed the exploration of how creative skills instruction is built into existing engineering courses. Some instances of creativity pedagogy may remain unobserved because they were not a part of the specific courses sampled.

\section{Case Study Sample}

We chose to focus on a Midwestern public university with a Carnegie Classification as a research university with very high research activity (RU/VH). Its college of engineering enrolls over 8,000 students and offers degrees in a variety of departments and multidisciplinary programs.

The sample size for case study research is traditionally small; a single case is commonly acceptable (Baxter \& Jack, 2008; Flyvbjerg, 2011; Gerring, 2005; Thomas, 2011; Yin, 2009). Our case study included data collected from seven separate engineering courses to capture multiple places within the curriculum where creative skills may be incorporated into pedagogy. The specific courses included in the study were identified as having a focus on creative skills by an associate dean in the College of Engineering, a faculty committee for enhancing creativity on campus, and professional staff who advise faculty on instructional techniques. Our main 
concern was to maximize our likelihood of capturing creative opportunities integrated into engineering courses. Of the nine courses identified, instructors of seven agreed to participate in the study, and they confirmed that creativity was a learning objective for their course.

Of these seven engineering courses, five had titles and descriptions explicitly emphasizing design. Design courses are often cited as providing opportunities for creativity, so it was not surprising that these courses were recommended. Two of the seven courses were undergraduate introductory engineering (100- and 200-level) courses, three were upper-level (300- and 400-level) undergraduate courses, one was a combined graduate and undergraduate course, and one was an introductory graduate course. Including this range of courses allowed for the observation of creative skill pedagogy across levels of instruction. Two of the design courses were cross-disciplinary and drew students from various disciplines in engineering as well as from other colleges within the university. The other five courses provided domain-specific instruction across a range of disciplines, including biomedical engineering, electrical and computer engineering, materials engineering, and mechanical engineering. The courses took place during the same semester.

\section{Data Collection}

In line with the case study approach, a variety of data types and collection methods were used (Case \& Light, 2011; Creswell, 1994; Flyvbjerg, 2001, 2006; Patton, 2001; Punch, 1998). We interviewed each instructor and up to two students in each course, surveyed the entire class toward the end of the semester, and gathered key course materials (e.g., syllabus, assignments, lecture materials, and project descriptions). This diverse dataset allowed us to gain a comprehensive understanding of course requirements and activities, the instructor's goals and pedagogical approaches, and the perspectives and experiences of students in each course.

During the instructor interviews, we asked instructors to describe the goals of the course associated with creativity along with the related instruction and assessments. The interviews were semistructured, lasted approximately an hour, and were audio-recorded. To facilitate the flow of the interview, we used the term "creative process" to indicate all of the related activities involved in creative skills. The interview protocol was pilot-tested with two instructors of nonengineering courses to ensure that the questions were understandable, and that they facilitated a flow of information pertinent to our research questions. Example questions were:

Can you describe to me a situation that would demonstrate a student is engaged in a successful creative process in your course? What are key components in a successful creative process?

When students leave your course, what do you want them to know about the creative process?

Can you describe a technique or lesson or project that you do as part of your class that you think is important in helping students develop their knowledge and skills of a creative process? What makes it successful?

How do you know if students are successful in improving their creative process skills?

How successful do you think the course is in helping students with their creative process?

Student interviews were conducted and focused on gathering the same types of information as in the instructor interviews about students' experiences in the courses. We aimed to interview two students in each course, and recruited them through an e-mail message inviting volunteers 
and offering a $\$ 15$ incentive. Confidentiality was guaranteed to participants; thus instructors did not know which students participated. We piloted the protocol with two students to ensure they understood the questions about how the course goals, instruction, and assessments affected their creative growth. Example questions in the protocol were:

What do you think your instructor wanted you to learn about creative processes?

Can you tell me about a specific experience in class where you think your creative process skills improved?

How did the instructor teach about creative processes?

In what ways did your instructor give feedback on your creative process skills development?

What do you think helped most in developing your creative process?

The final survey provided a more complete picture of how the class as a whole viewed course activities and their relationship to creativity development. The survey was short and required approximately 20 minutes to complete. We piloted this instrument with 50 students taking a course that was not part of our case study population. Revisions were made according to clarification questions students asked as they were completing the survey as well as their responses to the questions. Example items in the final survey that were used to gather additional student perspectives were:

How much do you think your creative process skills developed as a result of this course?

List the three projects/activities/lectures/assignments, etc. that you think most impacted your creative process skill development. Please also explain why and how they affected your development.

Are there any elements that you felt were missing from the course that you think would have benefitted your creative process skills? What are they? Why do you think they would have helped?

We collected course materials for seven courses, completed seven instructor interviews and ten student interviews, and collected survey data from 240 students (shown in Table 1). In Courses D and E, we were able to recruit only one student from each to interview. In Course F, we did not complete student interviews at the request of the instructor. All students present on the day we gave the survey agreed to participate.

\section{Data Analysis}

For each course, the instructor and student interviews, open-ended student surveys, and course materials were grouped together for analysis. The grouping method treated all of the materials for each course as a collection to provide a more complete understanding of the goals of the course, instructional methods, and assessments. The data triangulation provided a way to establish validity by analyzing the research question from multiple perspectives as well as providing the means to uncover deep meaning in the data (Patton, 2002).

We used a deductive coding approach, where the four thematic categories (see Defining Creativity above) were pre-identified (Fereday \& Muir-Cochrane, 2006) These four categories were selected for the analysis on the basis of evidence that training programs focusing on cognitive skills prove successful at improving creativity (Scott et al., 2004). We did not 
Table 1 Data Collected for Each Course

\begin{tabular}{|c|c|c|c|c|c|}
\hline $\begin{array}{l}\text { Course } \\
\text { code }\end{array}$ & $\begin{array}{l}\text { Instructor } \\
\text { interview }\end{array}$ & $\begin{array}{l}\text { Student } \\
\text { interviews }\end{array}$ & $\begin{array}{l}\text { Returned } \\
\text { surveys }\end{array}$ & $\begin{array}{l}\text { Enrolled } \\
\text { students }\end{array}$ & Course materials \\
\hline A & Instructor A & $\begin{array}{l}\text { Student A1 } \\
\text { Student A2 }\end{array}$ & 22 & 24 & Syllabus, course website \\
\hline $\mathrm{B}$ & Instructor B & $\begin{array}{l}\text { Student B1 } \\
\text { Student B2 }\end{array}$ & 30 & 38 & $\begin{array}{l}\text { Syllabus, assignment descriptions, lecture slides, } \\
\text { reading list, handouts, course website }\end{array}$ \\
\hline $\mathrm{C}$ & Instructor $\mathrm{C}$ & $\begin{array}{l}\text { Student C1 } \\
\text { Student C2 }\end{array}$ & 12 & 18 & Syllabus, lecture slides, course website \\
\hline $\mathrm{D}$ & Instructor D & Student D1 & 58 & 61 & $\begin{array}{l}\text { Syllabus, course description, lecture notes, } \\
\text { assignment descriptions, quizzes, course website }\end{array}$ \\
\hline $\mathrm{E}$ & Instructor E & Student E1 & 24 & 26 & Syllabus, course website \\
\hline $\mathrm{F}$ & Instructor F & none & 45 & 51 & Syllabus, course website \\
\hline G & Instructor $\mathrm{G}$ & $\begin{array}{l}\text { Student G1 } \\
\text { Student G2 }\end{array}$ & 49 & 79 & $\begin{array}{l}\text { Syllabus, lecture notes, schedule, assignments, } \\
\text { homework sets, labs, handouts, course website }\end{array}$ \\
\hline Total & 7 & 10 & 240 & & \\
\hline
\end{tabular}

include other categories from the Treffinger framework that described biographical (selfdescriptive) interests and personality traits such as tenacity and work ethic (Treffinger et al., 2002). We omitted these categories because they are static individual difference measures that do not change much over one's lifetime (Roberts, Walton, \& Viechtbauer, 2006), and so are unlikely to be affected by a semester-long course. The resulting coding scheme is shown in Table 2 with working definitions of the categories.

To organize our course analysis, we identified three separate components of courses using the backward design framework (Wiggins \& McTighe, 2005). This framework breaks down course design into three components: desired results, learning plan, and assessment evidence. Wiggins and McTighe (2005) proposed that these three components should be aligned so that desired results are clearly stated, assessments are based on evidence of obtaining the desired results, and then a learning plan is constructed to support students in achieving the desired results (cf. Biggs, 2003). For each of the courses in the study, we assessed each of the creativity indicators as to whether it was included in all three of these course components: as a learning goal, practiced or discussed in instruction, and included in assessments.

A team of independent raters separately coded the data after completing a training sequence in which they read Treffinger et al. (2002), practiced coding one case of data, and compared and discussed this practice coding with the team of coders. A rater first reviewed the data collected for each course and then coded according to the 18 separate indicators in Treffinger et al.'s (2002) four major categories as well as the three components of the design framework (Wiggins \& McTighe, 2005). Then, a second rater reviewed the raw data and then the first rater's coding to identify any gaps or discrepancies, and kept track of any changes to the original coding. Once raters completed coding, they discussed disagreements to reach consensus. Finally, a third rater reviewed all of the coded data for the seven courses to confirm consistency in the raters' interpretation of the coding scheme. This procedure using two independent coders and a final third coder supported dependability of our findings. 
Table 2 Coding Scheme for

Cognitive Aspects of Creativity

\begin{tabular}{|c|c|}
\hline Indicator & Working definition \\
\hline \multicolumn{2}{|l|}{ Generating Ideas } \\
\hline Fluency & Generating a large number of ideas in response to an open-ended question \\
\hline Flexibility & Shifting the direction of one's thinking or changing one's point of view \\
\hline Originality & Generating new and unusual ideas \\
\hline Elaboration & Adding details and expanding ideas \\
\hline Metaphorical thinking & Using comparison or analogy to make new connections \\
\hline \multicolumn{2}{|l|}{ Digging Deeper into Ideas } \\
\hline Analyzing & Breaking down an idea into components to understand them \\
\hline Synthesizing & Combining two different themes within an idea \\
\hline Reorganizing or redefining & Revisiting information to change its form \\
\hline Evaluating & Appraising the potential value of ideas \\
\hline Seeing relationships & Drawing connections between different ideas \\
\hline $\begin{array}{l}\text { Desiring to resolve } \\
\text { ambiguity/bringing } \\
\text { order to disorder }\end{array}$ & Organizing disparate components \\
\hline \multicolumn{2}{|c|}{ Openness and Courage to Explore Ideas } \\
\hline Problem sensitivity & Seeking out and identifying problems \\
\hline Aesthetic sensitivity & Attempting to make pleasing formulations of ideas \\
\hline Fantasy and imagination & Considering "unreal" or "impossible" ideas \\
\hline Tolerance for ambiguity & Allowing openness to uncertainty within a problem \\
\hline Intuition & Drawing upon an internalized understanding \\
\hline $\begin{array}{l}\text { Integration of dichotomies } \\
\quad \text { or opposites }\end{array}$ & Incorporating opposing ideas \\
\hline \multicolumn{2}{|l|}{ Listening to One's Inner Voice } \\
\hline Metacognition & $\begin{array}{l}\text { Combining (a) reflecting on the cognitive processes underway } \\
\text { (introspection) and (b) awareness of creativity }\end{array}$ \\
\hline
\end{tabular}

Note. Adapted from Treffinger et al. (2002).

\section{Findings}

In the following section, we discuss the data as a collection and provide specific examples of the evidence collected within each category. Table 3 provides a summary of our findings, with each course mapped by evidence for the Treffinger et al. (2002) creativity indicators and divided into the three course components of the backward design framework (Wiggins \& McTighe, 2005). The letters A through $\mathrm{G}$ represent the courses, and "none" indicates there was no evidence in any of the classes for the coding combination.

This analysis revealed that the engineering courses focused on convergent creative skills (Digging Deeper into Ideas), evident in the desired results, learning plans, and assessment evidence for these skills. Engineering curricula are especially strong in analytical skills; thus, it was not surprising that analysis, redefinition (iteration), and evaluation were cornerstones for the courses in our study. For example, in Course A, the value of redefinition (iteration) was clearly articulated, as evident in the course syllabus, student interviews and surveys, and instructor interview. The desired result was that students practice this process of redefinition (iteration) and become aware of its importance in problem solving and design. The learning 
Table 3 Summary of Course Alignment with Treffinger et al. (2002) Framework

\begin{tabular}{|c|c|c|c|}
\hline $\begin{array}{l}\text { Creativity } \\
\text { operator }\end{array}$ & $\begin{array}{l}\text { Desired } \\
\text { results }\end{array}$ & $\begin{array}{l}\text { Learning } \\
\text { plan }\end{array}$ & $\begin{array}{c}\text { Assessment } \\
\text { evidence }\end{array}$ \\
\hline \multicolumn{4}{|l|}{ Generating Ideas } \\
\hline Fluency & $\mathrm{A}, \mathrm{B}, \mathrm{C}$ & $\mathrm{A}, \mathrm{B}, \mathrm{C}, \mathrm{E}$ & $\mathrm{B}, \mathrm{C}$ \\
\hline Flexibility & $\begin{array}{c}\mathrm{A}, \mathrm{B}, \mathrm{C}, \mathrm{E} \\
\mathrm{F}, \mathrm{G}\end{array}$ & $\mathrm{A}, \mathrm{B}, \mathrm{E}, \mathrm{F}$ & none \\
\hline Originality & $\mathrm{B}, \mathrm{C}, \mathrm{D}, \mathrm{E}$ & $\mathrm{D}, \mathrm{E}$ & $\mathrm{D}$ \\
\hline Elaboration & none & $\mathrm{C}, \mathrm{D}$ & none \\
\hline Metaphorical thinking & G & $\mathrm{F}$ & none \\
\hline \multicolumn{4}{|l|}{ Digging Deeper Into Ideas } \\
\hline Analyzing & $\begin{array}{l}\text { A, B, C, D, } \\
\text { E, F, G }\end{array}$ & $\mathrm{B}, \mathrm{C}, \mathrm{F}, \mathrm{G}$ & $\begin{array}{c}\text { A, B, C, D, } \\
\text { E, F, G }\end{array}$ \\
\hline Synthesizing & C, E, G & $\mathrm{D}, \mathrm{E}$ & A \\
\hline Reorganizing or redefining & $\begin{array}{c}\text { A, B, C, D } \\
\text { E, F, G }\end{array}$ & $\begin{array}{l}\text { A, B, C, D } \\
\text { E, F, G }\end{array}$ & $\begin{array}{c}\mathrm{A}, \mathrm{B}, \mathrm{C}, \mathrm{D}, \\
\mathrm{E}, \mathrm{F}\end{array}$ \\
\hline Evaluating & A, C, F & $\begin{array}{c}\mathrm{A}, \mathrm{B}, \mathrm{C}, \mathrm{D} \\
\mathrm{E}, \mathrm{F}\end{array}$ & $\begin{array}{c}\text { A, B, C, D, } \\
\text { E, F, G }\end{array}$ \\
\hline Seeing relationships & none & none & none \\
\hline $\begin{array}{l}\text { Desiring to resolve } \\
\text { ambiguity/bringing } \\
\text { order to disorder }\end{array}$ & $\mathrm{A}, \mathrm{C}$ & $\mathrm{C}$ & none \\
\hline \multicolumn{4}{|c|}{ Openness and Courage to Explore Ideas } \\
\hline Problem sensitivity & $\begin{array}{l}\text { A, B, C, D, } \\
\quad \text { E, F, G }\end{array}$ & $\begin{array}{c}\text { A, B, C, D, } \\
\quad \text { E, F }\end{array}$ & none \\
\hline Aesthetic sensitivity & $\mathrm{D}$ & none & A \\
\hline $\begin{array}{l}\text { Fantasy and } \\
\text { imagination }\end{array}$ & $\mathrm{A}, \mathrm{C}$ & A, E, G & none \\
\hline $\begin{array}{c}\text { Tolerance for } \\
\text { ambiguity }\end{array}$ & $\mathrm{A}, \mathrm{C}, \mathrm{D}, \mathrm{F}$ & $\mathrm{A}, \mathrm{C}, \mathrm{F}$ & none \\
\hline Intuition & $\mathrm{C}, \mathrm{F}$ & none & none \\
\hline $\begin{array}{l}\text { Integration of } \\
\text { dichotomies or } \\
\text { opposites }\end{array}$ & none & none & none \\
\hline \multicolumn{4}{|l|}{ Listening to One's Inner Voice } \\
\hline Metacognition & $\mathrm{A}, \mathrm{B}, \mathrm{E}$ & $\begin{array}{c}\mathrm{A}, \mathrm{B}, \mathrm{C} \\
\mathrm{E}, \mathrm{F}\end{array}$ & $A, B$ \\
\hline
\end{tabular}

plans involved multiple rounds of building representations, testing ideas, presenting ideas, and gathering feedback, and also included post-presentation discussions on how the proposed outcome changed over time and what next steps could be taken to make it better. Students were assessed for their level of experimentation, thorough investigation of design ideas, and level of iteration at the end of the semester through the use of a rubric.

Another trend was the presence of desired results and learning plans related to divergent thinking (Generating Ideas), most often related to fluency, flexibility, and originality. In a few cases, course structures also included assessment evidence related to divergent thinking. For example, Course B had clearly articulated desired results related to idea fluency. Fluency 
was discussed by the instructor, evident in the course materials, and affirmed by the students in interviews and the open-ended survey. The learning plan related to fluency involved multiple exercises, where the instructor would give students a time limit and a quantity goal for idea generation. Students were assessed through regular reports in which they listed a certain number of ideas in order to receive full credit.

Problem sensitivity, in Openness and Courage to Explore Ideas, was also prominent in the desired results and learning plans. For example, in Course C, the instructor had a clear, desired result for students to understand the problem context. The learning plan required students to interview potential customers in order to more deeply probe and shape the constraints of their problem. This desired result was also evident in Course E, whose learning plan included regularly bringing in stakeholders to work with students on identifying an existing problem. While there was some evidence regarding tolerance for ambiguity, it and other creative indices were observed less frequently within this category.

The final category, Listening to One's Inner Voice, was not often expressed as a desired result, but five of the courses included occasions for students to reflect on their processes as part of the learning plans. In Course F, the instructor devoted time in multiple class sessions for students to investigate personal biases and their effect on the choices made in problemsolving approaches, data collection, and interpretation of findings. The activity helped students evaluate their decision-making processes, and become more aware of their approaches and how they made decisions.

These findings, though, also show that many categories of creative skills were not addressed by any of the courses, and for many of the creative skills, the desired results, learning plans, and assessment evidence did not align. For example, the convergent skill of synthesizing was a goal for three courses; yet, only one of the three courses which cited synthesizing as a goal included instruction in it, while another included instruction in it without a clear learning goal, and a third included assessment related to the ability to synthesize, yet did not state a learning goal or include instruction focused on synthesis. These omissions are discussed further in the Discussion section. The following sections provide more detail about how instructors stated goals, provided lessons and activities, and assessed student learning related to creative skills. Multiple examples are presented to demonstrate the various ways instructors incorporated creative skills in their courses, and to suggest ways to use these practices in other courses. The appendix presents additional examples of comments observed within each category in Table 2. Instances of categories that lacked data support are discussed in a later section.

\section{Generating ldeas}

The generation of ideas is often considered an example of divergent thinking, where different answers are generated for a given problem (Guilford, 1967). In the engineering courses in our study, students were primarily generating ideas for solutions, but in two of the courses, idea generation also took place as students were exploring possible problems for which they would later generate solutions. Thus, we considered both generating ideas for solutions and generating ideas for problems in our analysis.

Desired results All of the instructors expressed learning goals related to at least one aspect of idea generation in their courses. In the design courses, instructors often focused on the desired result of students' ability to suggest multiple solutions for design. Only two instructors explicitly articulated desired results related to flexibility in generating ideas. Of these two, one instructor explained that he wanted students to learn to "let go" of previous bias and consider problems in new ways: 
Coming up with ... optimal solutions that, not too constrained by bias, previous bias. (Instructor interview, Course C)

Likewise, the other instructor taught a technical disciplinary engineering course with relatively structured content. He described flexibility as a desired result in that he wanted students to be able to apply knowledge from other domains to their understanding of the course material. Only one instructor described the desired result of metaphorical thinking, emphasizing drawing connections between the concepts and relationships within a specific engineering discipline to similar relationships in other fields:

Whenever they see a circuit, I'd like to have them see the underlying input/output relationships between what signals might be doing before they go through that circuit and what they're going to be doing when they come out. I would then also like them to be able to see that same input/output relationship could be explained using mechanical components, using chemical components, using economic components, using social psych components, using whatever. (Instructor interview, Course G)

Learning plan In all of the courses except Course G, there was evidence of learning plans related to Generating Ideas. The indicator fluency was often observed in strategies to help students with the flow of ideas. Course E placed a heavy emphasis on fluency and used class time and structured assignments to help students generate multiple possibilities. The instructor implemented traditional brainstorming methods, but also provided students with a variety of information-gathering experiences (with clients, doing research, etc.) to seed additional idea generation:

I've been a part of several brainstorming sessions. So with the class I'm taking, we had to do that about eight times. ... So a clinician, a doctor, would come in and tell us a problem that he had, and we'd brainstorm solutions to his problem. (Student interview, Course E)

In other classes, information-gathering experiences took place, but were rarely paired with additional activities, instruction, or assignments to facilitate using that knowledge to increase fluency. Some instructors encouraged students to consider the problem from different perspectives. For example, in Course A, the instructor stated that flexibility was facilitated by using reverse engineering both to initiate a solution to a problem and to find a new problem. In one multidisciplinary design class, Course B, the instructor had students work through classic problems designed to "drive them crazy because the answer should be obvious." The students then discovered why their conventional approaches may be limiting by "defining the problem either differently or too narrowly." Adding differing perspectives by working in teams with students from other disciplines was another method used in two courses. While many instructors listed originality as a desired result, there was rarely any evidence of explicit instruction associated with these stated goals. Most frequently, instructors relied upon learning plans that included open-ended problems as the method for generating original solutions. One instructor described such an open-ended approach:

Allow students to do whatever they wish. Provide guidelines but make them fairly broad and general. (Instructor interview, Course D)

Evidence of elaboration during idea generation (such as elaborating on possible problems) was seen in Courses C and D. Learning plans focused on collecting observational data 
related to the problems under consideration, as well as talking with stakeholders. Metaphorical thinking was evident in the learning plan of only one course. Using comparison or analogies to make connections and formulate new ideas can be a very powerful creative tool, although only two instructors alluded to the use of analogies as a tool in their classrooms.

Assessment evidence Although all instructors expressed desired results and most described learning plans related to idea generation, there was very little use of assessment evidence in the courses. In two of the courses (Courses B and C), it was specified on assignments that students should include a specific number of concept ideas to receive full points. But in all other classes, none of the materials indicated that instructors used any method to assess the fluency of student ideas. Only one class (Course D) explicitly included assessment evidence of students' originality as points contributing to grades, where students' final project received one to five points (out of 100) on the basis of the originality of the design. In the other classes, instructors often gave feedback on students' ideas; they presumably were influenced by how original they thought students' ideas were. Assessment evidence of originality was not explicitly present in any of the other assignment documents or data collected about the courses. Additional data for the indicators in the Generating Ideas category are included in the appendix.

\section{Digging Deeper into Ideas}

Convergent thinking involves identifying solutions that fit many constraints at once (e.g., Brophy, 2006; Cropley, 2006; Finke et al., 1992; Guilford, 1967). A traditional view of engineering expertise would include a heavy emphasis on these analytical skills. While instructors and students explicitly linked divergent thinking activities to the development of creative skills, rarely did they link convergent indicators to creativity. Yet convergent thinking skills are an important aspect of the creative process, and there was a great deal of evidence for convergent skill building in the courses.

Desired results Analyzing was a key desired result for each of the courses in our study. Analysis, such as breaking a problem into subparts and determining relationships among them, was apparent in all of the courses. Each had desired results aimed at supporting students' ability to think deeply about the problems, contexts, and ideas, and how data could be collected to inform their approach to addressing a problem. Desired results related to analysis also included developing students' ability to determine which aspects of problems were important and their ability to compare ideas they had generated to existing products in the marketplace. Likewise, many of the courses included desired results for students to synthesize ideas, information, and perspectives. Reorganizing or redefining was evident as a learning goal, specified as iteration, or repeated attempts to solve a problem.

Evaluating was another convergent creativity indicator that played a central role in the courses in our study. Desired results for students' skills in evaluation came in multiple forms, including the ability to develop tests to evaluate the effectiveness of a product, material, or function; identifying gaps and strengths in one's own ideas or other existing ideas; and building a case to prove to someone else that an idea is worth the investment. Resolving ambiguity was only rarely reflected in desired results across courses.

Learning plans Instructors in all of the courses described learning plans that allowed students to engage in activities where they developed and practiced the convergent skills related to Digging Deeper into Ideas. In many of the courses, students presented their ideas along with an analysis of why they chose the idea that they did, and why that idea was different from others already in existence. A key component for many of the courses was analyzing data collected 
through self-designed experiments to test ideas. For one of the non-design classes, this focus also meant that much of the class time was spent practicing and discussing analysis.

Only two of the courses (D and E) contained evidence of explicit learning plans related to synthesis. In one course, the instructor had project teams share interesting features of their designs, and other teams were then supposed to synthesize some of these aspects with their own projects:

We'll have a "how'd they do that" session. And a "how they do that session" is that you saw on somebody else's [project] that they had blinking blue lights in the background. ... So that group will stand up and say, you know, "how we did the blinking blue lights is ... blah." And then they explain the process, and it's, okay, we'll incorporate that; we'll put a little bit of a different twist on it. You know, we'll have blinking red lights instead of blue lights, but we're going to use that methodology somehow. (Instructor interview, Course D)

In the other course, synthesis had a significant role because the instructor asked students to merge characteristics of multiple ideas together. As a learning plan, the instructor had student teams submit their ideas on a wiki so everyone could see the ideas. They then spent time in class synthesizing those ideas, guided by the instructor.

Many courses also included learning plans related to reorganizing or redefining, in terms of iteration and redefining ideas, even in the two nondesign courses. Check-in points, feedback sessions, critique, and prototyping were common in the learning plans related to iteration. Many types of learning plans had students engage in evaluation in multiple contexts, such as gaining the ability to develop metrics and use the outcomes to evaluate choices and then make decisions, building prototypes to evaluate if targeted functions were successful, evaluating their own ideas and those of their classmates, and designing reviews. Students engaged in evaluation activities that required them to specify the value of an idea by generating evidence to show that an idea would be a better competitor than other potential ideas or existing products:

The course was also ... coming up with a model to prove that your product would beat competitors so ... how do you figure out analytically whether your product is better than another product? It essentially comes down to weights of different attributes. (Student interview, Course B)

Only one course specified an explicit learning plan to resolve ambiguity in problem solving.

Assessment evidence In the design courses, assessing students' analysis skills was often tied to their own evaluation of the feasibility of their designs and justification of choices. Written reports and oral presentations were required, but there were no explicit evaluations in the grading rubrics for these analytical reports. In the two nondesign courses, homework problems and laboratory reports played a similar role.

Only one course included assessment evidence related to synthesis. In Course A, a project-based course, an instructor specifically noted students would be assessed for their projects' form as it relates to its function:

Design Criteria: How was your team able to synthesize the form, function and behavior of the surface? (Syllabus, Course A)

Synthesis was an expressed criterion for assessment, but how success in synthesis was equated with specific scores was unclear from the materials. 
Assessment evidence of students' ability to reorganize and refine (iterate) occurred through periodic reports or presentations of design ideas. Students were expected to present an updated version of their idea based on additional information gathered, feedback received, and data collected from tests of their prototypes. Grading rubrics for project milestones listed aspects of iteration as components that composed the final grade. In many classes, project requirements specified that students build multiple prototypes during the course.

Assessment evidence of students' ability to evaluate ideas was implied in assignments in all of the courses that required students to evaluate their own and others' work. However, there was no mention of specific assessment criteria for the content of students' evaluation. Additional data for the indicators in the Digging Deeper into Ideas category are given in the appendix.

\section{Openness and Courage to Explore Ideas}

This category includes characteristics related to exploration of problems and solutions. Learning to go beyond the immediate impression to investigate conflicting ideas, continuing through repeated attempts, and responding to failure are important in creative endeavors (Treffinger et al., 2002).

Desired results All of the instructors expressed desired results for students related to at least one skill in Openness and Courage to Explore Ideas. The notion of problem sensitivity is related to "problem finding," where one identifies specific problems to solve (Getzels, 1975 , p. 13). This was mentioned as a goal in all the courses studied. Some instructors expressed a desire for their students to develop problem identification strategies as a starting point for their design work, while others specifically emphasized the ability to identify valuable problems, not necessarily within expected constraints:

The thing is, you know, we say, "well okay, that's what you can work on," and then there's the high-value problem. So what's the highest value problem for your team? And that might not be the most complex thing. It might not be the most beneficial thing. (Instructor interview, Course A)

Very few engineering instructors mentioned desired results related to aesthetic sensitivity. In one computer game design course, the instructor explained students had the option of adding art to their projects; however, he did not explicitly identify aesthetic sensitivity as a goal, or as something he actively tried to facilitate through instruction. Similarly, fantasy and imagination may seem, on the surface, far from the realm of engineering, yet creativity may require identifying possibilities that are currently impossible or not yet experienced. In several classes, instructors specifically expressed desired results in terms of students' ability to play and explore things that interested them, regardless of practical considerations.

Many of the engineering instructors expressed desired results of students' development of tolerance for ambiguity, or comfort with exploring new, ill-defined ideas as a result of their experiences. Several engineering instructors explained that, unlike other engineering courses in which answers are known or knowable, it was their goal to help students learn by exploring topics where little was known or defined. Several instructors acknowledged that students are often at least initially uncomfortable with exploring the unknown. One instructor asserted that promoting discomfort was his goal, and that he saw discomfort as a sign of students' growth in creativity:

I think I want them to feel uncomfortable, and if they are feeling very uncomfortable, it's because they are doing something new and, I think, exploring new areas that they would not do outside this course. (Instructor interview, Course C) 
Intuition is an internal sense of direction based on accumulated experience that is often difficult to describe in rational terms (Klein, 1998, 2003). Knowing when to follow intuition is likely a difficult skill to teach; however, several instructors described their desired result in terms of developing their students' intuition through knowledge of the field and helping students internalize their understanding of how to approach challenges.

Learning plans All of the courses included learning plans meant to develop students' skills related to Openness and Courage to Explore Ideas. There were many learning plans intended to help students gain greater problem sensitivity. In some design courses, instructors introduced students to potential stakeholders so they could learn more about their target users. The customer orientation surfaced frequently in interviews with instructors:

I do in a very organized way, using this axiomatic design process. That first goal for the students is to ... find out what the potential customers are, who they are. And then to interview them to try to find out what the project is about and then have a formal list of requirements, and then one stage initially is just a more qualitative list of requirements, and then to quantify those, and then go into what are the functions that they have to implement to satisfy the customers. (Instructor interview, Course C)

Several courses also included learning plans related to students' capacity for fantasy and imagination. Instructors reported addressing capacity for imagination in their learning plans through encouraging students to explore topics that interested them, and by doing what they could to facilitate exploration:

So by creating the opportunity, funding the projects, you, know, get leverage in them, access to the facilities, you know? This being a special type of experience and there's also a skunk works phenomena, you know. Then I think it helps them invest to a certain point. (Instructor interview, Course A)

Learning plans focused on tolerance for ambiguity presented students with opportunities to explore undefined problems, or problems where the solution was not previously determined.

Assessment evidence There was very little explicit assessment evidence related to students' exploring new concepts and ideas in the courses studied. One course (Course A) included an assessment of aesthetic success in the final product. Additional data for the indicators in the Openness and Courage to Explore Ideas category are included in the appendix.

\section{Listening to One's Inner Voice}

The ability to reflect on the course of one's efforts and make corrections or consider new steps is a key to developing creative skills. The characteristics that compose the Listening to One's Inner Voice category (Treffinger et al., 2002) were combined in the analysis to include both reflection and awareness of one's own creative process. Metacognition is defined as "reflective thinking" to capture this self-knowledge of cognitive processes (Flavell, 1979, p. 908).

Desired results Although many instructors described learning plans intended to facilitate students' metacognition about their work and their own creative processes, very few expressed desired results in these terms. One instructor described his intentional approach to teaching students about creativity as a way to make students conscious of their own creative process:

I have a main creativity lecture mostly to get them to think about it in a conscious way. (Instructor interview, Course B) 
Learning plans Instruction and course activities related to metacognition varied greatly. In one course, the instructor felt that simply making it known that a creative outcome was required would force students to explore their own creative abilities. In several design courses, learning plans on metacognition involved written assignments such as course blogs or a paper requiring students to reflect on their work, design approaches, and interests. One instructor asked students to identify their own biases and how they may affect their work:

We do draw comparisons between whether something is potentially easier to do or something that's potentially more robust or more accurate. We do ... spend a lot of time thinking about where our bias is in the sort of measurements that we actually do generate. (Instructor interview, Course F)

In another course, the instructor had students perform self-awareness exercises and take a behavioral assessment in order to get a better understanding of their own interests and work styles. The instructor identified these reflective exercises as a way to facilitate better teamwork, which is frequently a critical part of the creative design process in engineering:

Midway through the year, I do a self-awareness exercise which is basically using the DiSC analysis, which is a behavioral assessment, and the idea is, the DiSC assessment basically tells you a little bit about who you are and your behavioral preferences when you are working in teams. [...] The idea is, if you understand what your behavioral language is, and you understand that of your partner or your teammates, then you might be more likely to communicate with them better. (Instructor interview, Course E)

Assessment evidence Although there was a significant amount of student work related to metacognition, little assessment evidence was evident in the data. In two courses, students were required to keep blogs, and in one, the instructor explained that one grading criterion was reflection. Otherwise, there was no explicit mention of assessment as it related to metacognition in the data. Additional data for the indicators in the Listening to One's Inner Voice category are included in the appendix.

\section{Discussion}

The detailed analysis in the previous section described observations about creative pedagogy as reflected in these existing engineering courses. In this section, we turn to the gaps in the categories from the analysis where no evidence was observed. Then, we discuss ways to increase opportunities for the development of students' creative skills in engineering. Finally, we address the study's limitations and directions for future work.

\section{What ls Missing in the Findings}

Our findings revealed that the pedagogy for many of the courses included convergent thinking skills such as analyzing, reorganizing, and evaluating. The results also highlight some gaps in creative skills instruction in engineering courses. Of course, other courses not included in our sample may address these gaps; however, because the instructors of the sampled courses cited fostering creativity as a goal, the absence of data in some areas of creative skills is informative. At the least, the gaps suggest areas where engineering curricula could be further developed.

While convergent skills were most often addressed in all of the courses, one Digging Deeper into Ideas skill, seeing relationships, was not evident in the desired results, learning 
plan, or assessment evidence in any of the courses. In the Generating Ideas category, the processes of elaboration and metaphorical thinking were rarely emphasized. Many skills in the category Openness and Courage to Explore Ideas were also not addressed across the courses; for instance, developing intuition and a tolerance for ambiguity are important skills within creative activities, because they most often involve risk taking and decision making under uncertainty. Arguably, aesthetic sensitivity is important for the tangible artifacts created by engineers, and its rare appearance in the data suggests more awareness and integration of aesthetics along with technical engineering content is possible.

Another gap across the dataset was the lack of assessments offered for many of the creative skills, including divergent thinking skills in most of the courses, and also for the skills in the Openness and Courage to Explore Ideas category. For example, originality was rarely explicitly assessed in any of the courses. This result is especially interesting because originality is a critical component of most operational definitions of creativity. Four instructors emphasized the idea of originality in their desired results, but only two of their courses had specific learning plans related to it, and only one course included an assessment.

The analysis also revealed a lack of alignment in the desired results, learning plans, and assessment evidence for many of the creative skills (Wiggins \& McTighe, 2005). Many times, there was clear evidence for one or two of the course building blocks from the backward design framework but no evidence of the third building block. While most often the missing piece was assessment, there were cases where no alignment occurred because of a lack of a clear learning goal or learning plan to address the creativity skill.

\section{Implications for Pedagogy}

Instructors could better support their students' development of creative skills by communicating clear learning goals in their courses. As best practices in instructional design would suggest (Wiggins \& McTighe, 2005), these specific creative goals should be carefully aligned with learning plans and appropriate assessments to provide a more complete learning experience.

Also, instructors could incorporate more assessments of specific creative skills and provide feedback to their students on improving these skills. Assessing creativity is not straightforward, but by breaking creativity into its component skills (Treffinger et al., 2002), assessments can be developed or adapted from existing assessments (e.g., Charyton \& Merril, 2009; Guildford, 1959; Kaufman, Plucker, \& Baer, 2008; O’Quin \& Besemer, 1989; Shah, Vargas-Hernandez, \& Smith, 2003; Torrance, 1974, 1981). For example, rubrics could be developed to evaluate students' levels of openness, actions taken to explore ideas, and depth of reflection. Because assessments play an important role in students' motivation to learn, omitting creative skill assessments from courses may limit the effect of instruction that does occur. Students may interpret a lack of assessment as an indicator of its lack of importance. Omitting assessment also limits instructors by preventing them from recognizing areas where students could benefit from additional support and development. One direction for assessment is to address specific learning about the creative process itself, rather than solely focusing on the specific project outcome. Students' explicit knowledge of cognitive indicators of creativity and self-awareness of the use of creative skills can be assessed, and would help to focus students' attention on these learning goals.

In addition to incorporating assessments of specific creativity indicators, this study revealed opportunities for improvements in instruction related to creative skills. In practice, instructors may rely on open-ended projects to provide opportunities for creativity. While project-based learning has been shown to be an effective pedagogy to support student engagement (Prince, 
2004; Smith, Sheppard, Johnson, \& Johnson, 2005), without explicit course design elements related to creative skills within these projects, this project-based approach may not actually improve creativity. In other words, an opportunity to be creative through an open-ended project is not equivalent to careful planning of specific desired results, learning plans, and assessment evidence of the creative skills to be developed.

Incorporating occasions for the development of students' creative skills throughout engineering curricula does not require an instructor to incorporate an open-ended project. Instead, an instructor can focus on one or more specific creative skill (guided by Treffinger et al.'s framework) and connect the goals, instruction, and assessments within the existing course material. Felder $(1985,1987,1988)$ described multiple ways he incorporated creative skills in the technical engineering courses he taught, for example, by including a homework question in which students had to suggest multiple ways a technical problem could be approached, thus providing practice and assessment in divergent thinking skills. Crismond and Adams's (2012) work provides multiple examples of classroom instruction to support both divergent and convergent thinking throughout design processes. Fogler and LeBlanc's (2013) textbook also describes many strategies to support students in creative problem solving.

We suggest additional ways to incorporate creative skill development in engineering courses.

Generating Ideas More attention could be given to instruction on originality, elaboration, and metaphorical thinking. Instruction related to originality could make use of practice with various ideation tools, e.g., Design Heuristics (Daly, Yilmaz, Christian, Seifert, \& Gonzalez, 2012a, 2012b; Design Heuristics, 2012; Yilmaz \& Seifert, 2011), morphological analysis (Allen, 1962; Zwicky, 1969), and SCAMPER (Eberle, 1995; Osborn, 1953). Instruction might include having students rate the originality of existing approaches or artifacts. An approach in art history is to examine a set of well-known exemplars to provide students with a sense of the scope of the field (Efland, 1990). Additionally, students could compare their own ideas to a pool of ideas gathered from the class as a whole; or they could be asked to generate ideas over a period of time and compare the originality of their early ideas to their later ideas. These methods could help students develop an awareness of the diversity of possible solutions. To develop elaboration skills, instructors could have students engage in a group ideation session where each person in the group adds an additional detail to a target concept. To support metaphorical thinking, Smith and Linsey (2011) propose ways to help students use analogies to specify the functions of a product (e.g., a design artifact) or process (e.g., a way to measure something, a procedure for solving a complex problem), and re-represent these functions with similar words. Such methods help students learn to create analogies back to their original task. Developing metaphorical thinking may require specific practice in the classroom with multiple examples (McKeogh et al., 1985).

Digging Deeper into Ideas Synthesizing and seeing relationships were two key skills not explicitly taught or practiced. An improvement of these skills through instruction could include having students compare and contrast multiple concepts, identify the best features of multiple ideas, and suggest ways to use these best features to develop new and improved ideas, rather than selecting just one idea with which to move forward. Performing an analysis of a range of exemplars, such as types of products, would allow students to see relationships across categories.

Openness to Explore Ideas Instruction related to aesthetic sensitivity could include giving examples of product aesthetics and data about their impact on adoption and marketability. Students could also be asked to gather aesthetic data on their own prototypes. Instruction on intuition could include giving students exposure to a large body of existing approaches, 
products, and processes, thus helping students develop an implicit understanding of the variety of possibilities within a given domain. The accumulation of a corpus of past solutions could serve as a basis for intuition on future projects.

Listening to One's Inner Voice A practice common in artistic and literary fields is to keep a journal record of thinking as a project unfolds. Writing exercises appeared to be less common in engineering classes, yet may serve as a method to encourage reflection about the creative process. Another method is to build in specific moments of reflection into the project process, when the group might meet specifically to discuss what has occurred during the development process. Alternatively, instructors might propose that students try a task by approaching it in different ways and reflecting on how those approaches affected their outcomes (Daly, Adams, \& Bodner, 2012). By focusing attention on choices made and the workflow during a project, the opportunity to make alternative choices in the future, or to recognize the need to do so, may become more apparent to students.

All of these learning activities provide an opportunity for instructors to use best practices in engineering education (e.g., Prince, 2004; Smith et al., 2005). For example, having students take five minutes in class to see how many different ideas they can generate for solving a problem provides an occasion for students to engage in active learning. Asking students to compare their approaches with each other makes use of group work. By considering learning activities to address a specific creative skill, instructors may more clearly see opportunities to build these into their course sessions and to facilitate student engagement.

Implications of this research include the provision of a common ground for definitions of creative skills along with which skills engineering programs should aim to develop in students. Perhaps some of the inconsistency in how courses implement training in creativity follows from instructors who have different ideas of what creativity means and how it can be assessed. For some engineering educators, creativity may remain an implicit process observed within an outcome, and not a cognitive skill that can be developed. Treffinger et al.'s (2002) framework is a starting place for discussions on the role of creativity instruction in engineering courses.

While a single course may not be able to incorporate all of the creative skills, or even all four categories of skills in this analysis, more careful program-level planning could add creative skills over time. By including goals, instruction, and assessment components for creative skills in courses, creative skills can be improved. As with all cognitive skills, considerable deliberate and intentional practice in creative skills may be required for students to reach the highest levels of expertise (Ericsson, Krampe, \& Tesch-Römer, 1993).

\section{Study Limitations and Future Work}

We aimed to identify evidence of creativity pedagogy in a sample of engineering courses identified as exemplars of creativity education within the college. The study was not intended to evaluate the quality of the courses nor to assess students' creative outcomes as a result of taking the courses. Each course had a different teaching approach, but the collection of courses allowed some conclusions about the opportunities they offered for students' development of creative skills. The present study did not, though, examine the effect of different forms of pedagogical approaches on students' actual development of creative skills.

The structure provided by the backward design model (Wiggins \& McTighe, 2005) could be a useful tool for designing creative skill pedagogies that align desired results, learning plans, and assessment evidence. For many of the creative skills in the study, instructors reported only one or two of the three components of course design, and careful attention to including all three components for each skill could have a significant positive effect on 
students' depth of learning. Further work is needed to identify specifically how to support educators in improving the interrelationships between these three course building blocks.

Evidence in our study was limited to course materials, interviews with instructors and students, and a written survey of students; as a consequence, these courses may include instruction on creative skills that were not captured in our findings. Other courses in engineering not in our sample may include alternative methods to support creative skill development. Our systematic description of these courses provides a substantial amount of evidence, and allows some important conclusions about ways to improve creative skills in engineering education.

For future work, we hope to use this case study as a foundation for a broader understanding of creative skills instruction. We suggest that examining pedagogy across disciplines may identify alternative methods that may prove practical in the engineering classroom and other settings.

\section{Conclusions}

The case study presented here has demonstrated the existence and nature of pedagogical efforts to develop students' creative skills within engineering courses. Our findings indicate that aspects of creative skill development are often missing from even exemplary engineering courses, and suggest that other courses are also likely failing to provide opportunities for students to develop their creative skills. While convergent thinking was well represented in engineering courses, divergent thinking skills require the development of further instructional techniques. Another area of potential pedagogical development is encouraging students to become open to exploring, rather than solving, problems. Methods to encourage students to embrace ambiguity, avoid premature closure, and increase reflection may greatly improve their creative skills. Developing assessments that will motivate students to improve their creative skills and increase awareness of their personal creative process is a key need in engineering pedagogy.

\section{Acknowledgments}

We are thankful to the following research assistants who helped with data analysis on this project: Amber Bellazaire, Christopher Johnson, Katie Korinek, Carly Sheridan, Emily Williams, and Tyler Zimmerman. Sam Goodman assisted with the data collection efforts on the project. We are grateful for project funding provided by the Office of the Vice Provost for Research, the School of Education, the College of Literature, Science, and Arts, the Department of Psychology, and the College of Engineering. We also thank James Holloway, Marvin Parnes, Theresa Reid, Crisca Bierwert, and Aileen Huang-Saad for their help in initiating this project.

\section{References}

Abercrombie, N., Hill, S., Turner, B. S., \& Erofeev, S. A. (1984). The Penguin dictionary of sociology. Harmondsworth, UK: Penguin.

Allen, M. (1962). Morphological creativity: The miracle of your hidden brain power. Englewood Cliffs, NJ: Prentice-Hall.

Altshuller, G. (1984). Creativity as an exact science. New York, NY: Gordon and Breach. Amabile, T. M. (1983). The social psychology of creativity. New York, NY: Springer-Verlag.

Amabile, T. M. (1996). Creativity in context: Update to the social psychology of creativity. Boulder, CO: Westview Press.

Antonucci, M. (2011). Sparks fly. Stanford Magazine, March/April, 1-6. 
Baillie, C., \& Walker, P. (1998). Fostering creative thinking in student engineers. European Journal of Engineering Education, 23(1), 35-44.

Baxter, P., \& Jack, S. (2008). Qualitative case study methodology: Study design and implementation for novice researchers. The Qualitative Report, 13(4), 544-559.

Besemer, S. P., \& O'Quinn, K. (1987). Creative product analysis: Testing a model by developing a judging instrument. In S. G. Isaksen (Ed.), Frontiers of creativity research: Beyond the basics (pp. 367-389). Buffalo, NY: Bearly.

Biggs, J. B. (2003). Teaching for quality learning at university (2nd ed.). Buckingham, UK: Open University Press/Society for Research into Higher Education.

Bransford, J. D., Brown, A. L., \& Cocking, R. R. (1999). How people learn: Brain, mind, experience, and school. Washington, DC: National Academy Press.

Brophy, D. R. (2006). A comparison of individual and group efforts to creatively solve contrasting types of problems. Creativity Research Journal, 18(3), 293-315.

Brown, A. L. (1987). Metacognition, executive control, self regulation, and other more mysterious mechanisms. In F. E. Weinert \& R. H. Kluwe (Eds.), Metacognition, motivation, and understanding. Hillsdale, NJ: Lawrence Erlbaum.

Bull, S., Montgomery, D., \& Baloche, L. (1995). Teaching creativity at the college level: A synthesis of curricular components perceived as important by instructors. Creativity Research Journal, 8(1), 83-89.

Case, J. M., \& Light, G. (2011). Emerging research methodologies in engineering education research. Journal of Engineering Education, 100(1), 186-210.

Charyton, C., \& Merrill, J. (2009). Assessing general creativity and creative engineering design in first year engineering students. Journal of Engineering Education, 98(2), 145-156.

Chen, C. K., Jiang, B. C., \& Hsu, K. Y. (2005). An empirical study of industrial engineering and management curriculum reform in fostering students' creativity. European Journal of Engineering Education, 30(2), 191-202.

Chi, M. T. H., Bassok, M., Lewis, M. W., Reimann, P., \& Glaser, R. (1989). Self-explanations: How students study and use examples in learning to solve problems. Cognitive Science, 13(2), 145-182.

Chi, M. T. H., de Leeuw, N., Chiu, M., \& LaVancher, C. (1994). Eliciting self-explanations improves understanding. Cognitive Science, 18(3), 439-477.

Creswell, J. W. (1994). Research design: Qualitative and quantitative approaches. Thousand Oaks, CA: Sage.

Crismond, D. P., \& Adams, R. S. (2012). The informed design teaching and learning matrix. Journal of Engineering Education, 101(4), 738-797.

Cropley, A. J. (2001). Creativity in education and learning: A guide for teachers and educators. London, UK: Kogan Page.

Cropley, D. H. (2006). The role of creativity as a driver of innovation. Proceedings of the 2006 IEEE International Conference on the Management of Innovation and Technology, Singapore, 561-565.

Cropley, D., \& Cropley, A. (2005). Engineering creativity: A systems concept of functional creativity. In J. C. Kaufman \& J. Baer (Eds.), Creativity across domains: Faces of the muse (pp. 169-185). Mahwah, NJ: Lawrence Erlbaum.

Cropley, D. H., \& Cropley, A. J. (2000). Fostering creativity in engineering undergraduates. High Ability Studies, 11(2), 207-219.

Csikszentmihalyi, M. (1996). The creative personality. Psychology Today, 29(4), 36-40. 
Daly, S. R., Adams, R., \& Bodner, G. (2012). What does it mean to design? A qualitative investigation of design professionals' experiences. Journal of Engineering Education, 101(2), 187-219.

Daly, S. R., Yilmaz, S., Christian, J., Seifert, C. M., \& Gonzalez, R. (2012a). Design heuristics in engineering concept generation. Journal of Engineering Education, 101(4), 601-629.

Daly, S. R., Yilmaz, S., Christian, J., Seifert, C. M., \& Gonzalez, R. (2012b). Uncovering design strategies. ASEE Prism, December, 41.

Design Heuristics. (2012). Design heuristics: Strategies to inspire ideas. Retrieved from http:// www.designheuristics.com

Dewulf, S. \& Baillie, C. (1999). CASE: How to foster creativity. London, UK: Department for Education and Employment.

Eberle, B. (1996). SCAMPER: Games and activities for imagination development. Waco, TX: Prufrock.

Efland, A. (1990). A bistory of art education: Intellectual and social currents in teaching the visual arts. New York: Teachers College Press.

Ericsson, K. A., Krampe, R. T., \& Tesch-Römer, C. (1993). The role of deliberate practice in the acquisition of expert performance. Psychological Review, 100(3), 363-406.

Felder, R. M. (1985). The generic quiz: A device to stimulate creativity and higher-level thinking skills. Chemical Engineering Education, 19(4), 176-181.

Felder, R. (1987). On creating creative engineers. Engineering Education, 77(4), 222-227.

Felder, R. M. (1988). Creativity in engineering education. Chemical Engineering Education, 22(3), 120-125.

Felder, R., Woods, D., Stice, J., \& Rugarcia, A. (2000). The future of engineering education: II. Teaching methods that work. Chemical Engineering Education, 34(1), 26-39.

Fereday, J., \& Muir-Cochrane, E. (2006). Demonstrating rigor using thematic analysis: A hybrid approach of inductive and deductive coding and theme development. International Journal of Qualitative Methods, 5(1), 80-92.

Finke, R. A., Ward, T. B., \& Smith, S. M. (1992). Creative cognition: Theory, research, and applications. Cambridge, MA: MIT Press.

Flavell, J. H. (1979). Metacognition and cognitive monitoring: A new area of cognitivedevelopmental inquiry. American Psychologist, 34(10), 906-911.

Flyvbjerg, B. (2001). Making social science matter: Why social inquiry fails and how it can succeed again. Cambridge, UK: Cambridge University Press.

Flyvbjerg, B. (2006). Five misunderstandings about case-study research. Qualitative Inquiry, 12(2), 219-245.

Flyvbjerg, B. (2011). Case study. In N. K. Denzin and Y. S. Lincoln (Eds.), The Sage handbook of qualitative research (4th ed., pp. 301-316). Thousand Oaks, CA: Sage.

Fogler, H. S., and LeBlanc, S. E. (2013). Strategies for creative problem solving (3rd ed.). Upper Saddle River, NJ: Prentice Hall.

Gardner, H. (1993). Creating minds. New York, NY: Basic Books.

Gerring, J. (2005). Case study research. New York, NY: Cambridge University Press.

Getzels, J. W. (1975). Problem-finding and the inventiveness of solutions. Journal of Creative Behavior, 9(1), 12-18.

Getzels, J. W., \& Csikszentmihalyi, M. (1976). The creative vision: A longitudinal study of problem finding in art. New York, NY: Wiley.

Grasso, D., Brown Burkins, M., Helble, J., \& Martinelli, D. (2008). Dispelling the myths of holistic engineering. PE Magazine, Aug/Sept. Retrieved from http:/www.nspe.org/ PEmagazine/pe_0808_Dispelling.html 
Guilford, J. P. (1950) Creativity. American Psychologist, 5(9), 444-454.

Guilford, J. P. (1967) The nature of human intelligence. New York, NY: McGraw-Hill.

Harvard Business School Press. (2003). Harvard business essentials: Managing creativity and innovation. Boston, MA: Author.

Howard, T. J., Culley, S., \& Dekoninck, E. (2008). Describing the creative design process by the integration of engineering design and cognitive psychology literature. Design Studies, 29(2), 160-180.

Ishii, N., Suzuki, Y., Fujiyoshi, H., Fujii, T., \& Kozawa, M. (2006). A framework for designing learning environments fostering creativity. In A. Méndez-Vilas, A. Solano Martín, J.A. Mesa González, \& J. Mesa González (Eds.), Current developments in technology-assisted education (pp. 228-232). Badajoz, Spain: Formatex.

Jablokow, K. (2001). The thinking expedition: A course in creativity, innovation and change. Proceedings of the 2001 ASEE Conference and Exposition, Albuquerque, NM.

Kaufman, J. C., Plucker, J. A., \& Baer, J. (2008). Essentials of creativity assessment. New York, NY: Wiley.

Kazerounian, K., \& Foley, S. (2007). Barriers to creativity in engineering education: A study of instructors and students perceptions. Journal of Mechanical Design, 129, 761-768.

Kirton, M. J. (2003). Adaption-innovation: In the context of diversity and change. New York, NY: Routledge.

Klein, G. (1998). Sources of power. Cambridge, MA: MIT Press.

Klein, G. (2003). Intuition at work. New York, NY: Bantam Dell.

Klukken, P. G., Parsons, J. R., \& Colubus, P. J. (1997). The creative experience in engineering practice: Implications for engineering education. Journal of Engineering Education, 86(2), 133-138.

Larson, M. C., Thomas, B., \& Leviness, P. O. (1999). Assessing creativity in engineers. Design Engineering, 102, 1-6.

Mumford, M. D. \& Gustafson, S. B. (1988). Creativity syndrome: e-integration, application, and innovation. Psychological Bulletin, 103(1), 27-43.

Mumford, M. D., Mobley, M. I., Uhlman, C. E., Reiter-Palmon, R., \& Doares, L. (1991). Process analytic models of creative capacities. Creativity Research Journal, 4(2), 91-122.

National Academy of Engineering. (2004). The engineer of 2020: Visions of engineering in the new century. Washington, DC: National Academy Press.

Nickerson, R. S. (1999). Enhancing creativity. In R. J. Sternberg (Ed.), Handbook of creativity (pp. 392-430). Cambridge, UK: Cambridge University Press.

O'Quin, K., \& Besemer, S. P. (1989). The development, reliability, and validity of the revised creative product semantic scale. Creativity Research Journal, 2(4), 267-278.

Osborn, A. (1953). Applied imagination: Principles and procedures of creative problem solving. New York, NY: Charles Scribner's Sons.

Pappas, J., \& Pappas, E. (2003). Creative thinking, creative problem-solving, and inventive design in the engineering curriculum: A review. Proceedings of the 2003 ASEE Annual Conference and Exposition, Nashville, TN.

Patton, M. Q. (1990). Qualitative evaluation and research methods (2nd ed.). Newbury Park, CA: Sage.

Patton, M. Q. (2001). Evaluation, knowledge management, best practices, and high quality lessons learned. American Journal of Evaluation, 22(3), 329-336.

Patton, M. Q. (2002). Qualitative evaluation and research methods (3rd ed.). Thousand Oaks, CA: Sage. 
Prahalad, C. K., \& Ramaswamy, V. (2003). The new frontier of experience innovation. MIT Sloan Management Review, 44(4), 12-18.

Prince, M. (2004). Does active learning work? A review of the research. Journal of Engineering Education, 93(3), 223-246.

Punch, K. R. (1998). Introduction to social research: Quantitative and qualitative approaches. Thousand Oaks, CA: Sage.

Rhodes, M. (1961). An analysis of creativity. Phi Delta Kappan, 42(7), 305-310.

Richards, G. (1998). Stimulating creativity: Teaching engineers to be innovators. Proceedings of the Annual Frontiers in Education Conference, 1034-1039.

Roberts, B. W., Walton, K. E., \& Viechtbauer, W. (2006). Patterns of mean-level change in personality traits across the life course: A meta-analysis of longitudinal studies. Psychological Bulletin, 132(1), 1-25.

Runco, M. A. (1991). The evaluative, valuative, and divergent thinking of children. Journal of Creative Behavior, 25, 311-319.

Schön, D. A. (1993). The reflective practitioner: How professionals think in action. San Francisco, CA: Jossey-Bass.

Scott, G., Leritz, L. E., \& Mumford, M. D. (2004). The effectiveness of creativity training: A quantitative review. Creativity Research Journal, 16(4), 361-388.

Seng, T. O. (2000). Thinking skills, creativity, and problem-based learning. Paper presented at the 2nd Asia Pacific Conference on Problem-Based Learning, December 4-7, Singapore.

Shah, J. J., Vargas-Hernandez, N., \& Smith, S. M. (2003). Metrics for measuring ideation effectiveness. Design Studies, 24(2), 111-134.

Shepard, J., \& Greene, R. W. (2003). Sociology and you. New York, NY: Glencoe/McGraw Hill. Sheppard, S., Macatangay, K., Colby, A., \& Sullivan, W. (2009). Educating engineers. Design for the future of the field. Carnegie Foundation for the Advancement of Teaching. San Francisco, CA: Jossey-Bass.

Smith, K., Sheppard, S., Johnson, D., \& Johnson, R. (2005). Pedagogies of engagement: Classroom-based practices. Journal of Engineering Education, 94(1), 87-101.

Smith, S., \& Linsey, J. (2011). A three-pronged approach to overcoming design fixation. Journal of Creative Behavior, 45(2), 83-91.

Soosay, C. A., \& Hyland, P. W. (2004). Driving innovation in logistics: Case studies in distribution centres. Creativity and Innovation Management, 13(1), 41-51.

Sternberg, R. J. (1998). The nature of creativity: Contemporary psychological perspectives. Cambridge, MA: Cambridge University Press.

Sternberg, R. J. (Ed.). (1999). Handbook of creativity. Cambridge, UK: Cambridge University Press.

Sternberg, R. J. (2000). Identifying and developing creative giftedness. Roeper Revierw, 23, 60-65.

Sternberg, R. J. (2001). What is the common thread to creativity: Its dialectical relation to intelligence and wisdom. American Psychologist, 56, 360-362.

Sternberg, R. J., \& Lubart, T. (1995). Defying the crowd: Cultivating creativity in a culture of conformity. New York, NY: Free Press.

Sternberg, R. J., \& Williams, W. M. (1996). How to develop student creativity. Alexandria, VA: Association for Supervision and Curriculum Development.

Stouffer, W. B., Russel, J., \& Oliva, M. G. (2004). Making the strange familiar: Creativity and the future of engineering education. Proceedings of the 2004 ASEE Annual Conference and Exposition, Salt Lake City, UT.

Thomas, G. (2011). How to do your case study. Thousand Oaks, CA: Sage. 
Thousand, J. S., Villa, R. A., \& Nevin, A. (1994). Creativity and collaborative learning: The practical guide to empowering students and teachers. Baltimore, MD: Paul H. Brookes.

Tolbert, D., \& Daly, S. R. (2013). First-year engineering student perceptions of creative opportunities in design. International Journal of Engineering Education, 29(4), 879-890.

Torrance, E. P. (1962). Guiding creative talent. Englewood Cliffs, NJ: Prentice Hall.

Torrance, E. P. (1974). Torrance tests of creative thinking: Norms and technical manual. Bensenville, IL: Scholastic Testing Press.

Torrance, E. P. (1981). Empirical validation of criterion referenced indicators of creative ability through a longitudinal study. Creative Child and Adult Quarterly, 6, 136-140.

Treffinger, D., Isaksen, S., \& Dorval, B. (2000). Creative problem solving: An introduction (3rd ed.). Waco, TX: Prufrock Press.

Treffinger, D., Young, G., Shelby, E., \& Shepardson, C. (2002). Assessing creativity: A guide for educators. Storrs, CT: National Research Center on the Gifted and Talented.

van Note Chism, N., Douglas, E., \& Hilson Jr., W. J. (2008). Qualitative research basics: A guide for engineering educators. Retrieved from http://cleerhub.org/resources/8

Wallach, M. A. (1970). Creativity. In P. Mussen (Ed.), Carmichael's handbook of child psychology (pp. 1211-1272). New York, NY: Wiley.

Weisberg, R. W. (1986). Creativity: Genius and other myths. New York, NY: Freeman.

Weisberg, R. W. (1999). Creativity and knowledge: A challenge to theories. In R. J. Sternberg (Ed.), Handbook of creativity (pp. 226-250). Cambridge, UK: Cambridge University Press.

Wiggins, G., \& McTighe, J. (2005). Understanding by design (Expanded 2nd ed.). Upper Saddle River, NJ: Pearson.

Wilde, D. J. (1993). Changes among ASEE creativity workshop participants. Journal of Engineering Education, 82(3), 167-170.

Woodman, R. W., \& Schoenfeldt, L. F. (1990). An interactionist model of creative behavior. Journal of Creative Behavior, 24(4), 10-20.

Yilmaz, S., \& Seifert, C. M. (2011). Creativity through design heuristics: A case study of expert product design. Design Studies, 32(4), 384-415.

Yin, R. K. (2009). Case study research: Design and methods (4th ed.). Thousand Oaks, CA: Sage.

Zwicky, F. (1969). Discovery, invention, research through the morphological approach. New York, NY: Macmillan.

\section{Authors}

Shanna R. Daly is an assistant research scientist in the College of Engineering, University of Michigan, 210 Gorguze Family Laboratories, Ann Arbor, MI, 48109; srdaly@umich.edu.

Erika Mosyjowski is a research assistant in the College of Engineering, University of Michigan, 210 Gorguze Family Laboratories, Ann Arbor, MI, 48109; emosy@umich.edu.

Colleen M. Seifert is an Arthur F. Thurnau Professor in the Department of Psychology, College of Literature, Science, and Arts, University of Michigan, 530 Church St., Ann Arbor, MI, 48109; seifert@umich.edu. 


\section{Appendix}

This appendix provides additional transcript, survey, and course material excerpts to allow readers to see examples of how instructors and students discuss aspects of creativity. The presentation of evidence follows the organization of materials in Table 2.

\section{Generating ldeas}

\section{Fluency}

We want to see you actively and thoughtfully explore many ideas, as opposed to perfectly polishing just one. (Instructor syllabus, Course A, Desired Results)

[The instructor said] I want you guys to quickly come up, within 5 minutes, come up with 20 ideas to address this and so [I] just started throwing out anything, regardless of how ridiculous it sounded. Because if you wanted 20, the first 5 or 6 seem feasible but after that you just have to ... throw out whatever, so that kind of helped I guess make you think more outside the box. (Student interview, Course B, Learning Plan)

One or more sections should address the following: Several conceptual solutions are described and evaluated relative to the stated objectives. (Course assignment, Course B, Assessment Evidence)

\section{Flexibility}

Because I'm asking them to now take the math that they've learned and begin seeing the world, the engineering world, through that math ... I need them to be able to see how do you take these ideas and put them back into their device world. (Instructor interview, Course G, Desired Results)

The fact that there are multiple ways to measure something similar suggests that there isn't one way to do things ... I'm not exclusionary, meaning that I don't ever come up and say well these are the only ways that you can measure this and forget about trying to do it some different sort of way. (Instructor interview, Course F, Learning Plan)

The reverse brainstorming ... you aren't always given a problem to solve. A lot of engineers are given problems and are expected to solve them but in a truly creative and innovative process you would have to be coming up with a problem yourself and identifying high-value problems. (Student interview, Course A, Learning Plan)

So my group ended up consisting of a music major, one guy who does sound engineering right now, one person who's in business, and one other mechanical engineer who isn't traditional, she's doing systems engineering and so if you're stuck with engineers it's fine but it's, you're kind of in one mindset, which I never really realized until I had the group around me and how they thought about ideas and they approached things was different and that I think really boosted my creative process. (Student interview, Course B, Learning Plan)

\section{Originality}

I would say when they [are able to] come up with a solution that has never been thought of before, a new solution to the maybe sometimes an old problem. (Instructor interview, Course C, Desired Results)

It's really open ended so that's really important to think about the whole design process starting with trying to discover what is really your task and taking the time, not 
rushing, really spending the time necessary to understand the project. [My approach is] I think hands off, trying to understand the reasoning behind the students' idea for a solution ... not trying to give them solutions, just guiding them a little but to sometimes see things that they are not seeing, or talking to the right people, or doing the right calculation. (Instructor Interview, Course C, Learning Plan)

It would probably be the open-ended nature of it. So I don't exactly teach them a framework and I go back and forth on whether or not a framework is a better thing or not. What I do is seed every piece of what they do. So I seed them. . .the idea is that it has to encourage them to go do a significant amount of work outside. And every year I have no idea if they're going to do it, right? It could be a total dud. (Instructor Interview, Course E, Learning Plan)

The laboratory class has sometimes included an open-ended laboratory investigation of students picking. So it's pretty free form and I don't want to put a lot of constraints on it. (Instructor Interview, Course F, Learning Plan)

\section{Elaboration}

I bring in eight to ten physicians, and the physicians actually present to the students what the clinical challenges are that they meet on a daily basis, what the limitations of those challenges are. We have the physicians come in and talk to the students. Then the students shadow the physicians. (Instructor interview, Course E, Learning Plan)

\section{Metaphorical Thinking}

Whenever they see a circuit I'd like to have them see the underlying input/output relationships between what signals might be doing before they go through that circuit and what they're going to be doing when they come out. I would then also like them to be able to see that same input/output relationship could be explained using mechanical components, using chemical components, using economic components, using social psych components, using whatever. (Instructor interview, Course G, Desired Results)

Students always love taboo sorts of things so I was telling at least one or two different groups of how you could actually design an alcohol sensor by building a component in and you could actually measure fermentation, if something were actually fermenting over time. You could actually come up with an electronic sensor or an electronic nose that would tell you when the beer or wine was done, an alternative breathalyzer. You know if you could do that you could also do a breathalyzer. (Instructor interview, Course F, Learning Plan)

\section{Digging Deeper into Ideas}

\section{Analyzing}

[The instructor] talked about how to do the analysis and why there were differences in products ... he really talked about that, and making you understand about all the products that are around you, why they are designed the way they are. Before I kind of designed blindly and I just looked at products and said, okay this one seems better than this. Or I didn't really look at competitive products, but to actually come up with a product and it to work in the marketplace, understanding how to compare which product is better, analytically come up with a number, that was important for me. (Student interview, Course B, Desired Results)

Literally the idea of putting boxes around things and understanding what is important to pay attention to and what they can ignore. Doing a figure ground at a problem 
solving level, I think is extremely important in helping these creativity skills along. (Instructor interview, Course G, Desired Results)

Writing a proposal really made me think on what my idea was, and analyze. Every aspect of it. It is crucial that your creative ideas can become real. (Student survey, Course D, Learning Plan)

What happens when your modulus value for mechanical behavior for one example is one tenth out of everybody else's and why is it? One reason is you didn't do the experiment correctly, one reason is that you're analyzing something incorrectly, one reason is you measured the wrong things, all three probably happen throughout the course but you know we try not to necessarily emphasize so much of that. The point is, hey, you got that wrong, let's figure out why we're getting it wrong and for those groups who did poorly on this particular piece we're going to actually reanalyze it collectively in front of the group. (Instructor interview, Course F, Learning Plan)

\section{Synthesizing}

Creative process is an iterative process of integrating knowledge from various sources and prototyping solutions to generate a creative output. (Student survey, Course E, Desired Results)

There were four different teams in the class and each team compiled all their ideas on a wiki so we combined our ideas on the board as well as the ideas from wiki. (Instructor interview, Course E, Learning Plan)

The assessment criteria to measure a team's achievement will be based on the following: How well the team is judged to integrate the capacities of the multidisciplinary team members. How well the design criteria developed early in the course are synthesized for defining the project and its goals (Syllabus, Course A, Assessment Evidence)

\section{Reorganizing or Redefining}

The value of iteration, that was really hit hard on. The realization that problems don't always come first, the value of just playing with things, and as long as you're playing and critically thinking about what you're doing then that can be a valuable approach. (Student interview, Course A, Desired Results)

Every module that we have requires them to rethink their assumptions that they made upfront and decide if they are still valid relative to the new aspect of design that they need to consider. Or they just have to sacrifice that aspect. (Instructor interview, Course B, Learning Plan)

They continue to make use of the same sort of general programming scheme, but each program is required to operate somewhat different. So they have to keep going back and updating what they have. The thought is that being able to go back and hopefully generate some comfort and familiarity with the fact that, I don't need to generate a brand new program, I can make use of a code that's already been developed. (Instructor interview, Course F, Learning Plan)

Experiment with media, materials, techniques and processes (hack and tinker); Commitment to a thorough investigation of design ideas via iterative research, drawings, calculations/modeling/models. (Syllabus, Course A, Assessment Evidence) 


\section{Evaluating}

Our students who are working in those particular realms need to be more observant as to how to be able to execute their own testing protocols in the absence of having a sort of large support structure around them. I think that's the biggest paradigm shift that I've observed over the last ten or twelve years. So as a result, our students need to be more equipped to be able to develop their own protocols, how to characterize, how to test something, how to evaluate something in some other way. (Instructor interview, Course F, Desired Results)

The course was also coming up with a model to prove that your product would beat competitors so ... how do you figure out analytically whether your product is better than another product? It essentially comes down to weights of different attributes. (Student interview, Course B, Learning Plan)

You have to have your major design ideas at one point and turn them in and evaluate which one's best. You take that one design and you test it and simulate it and all of that to make sure it's going to work. And the last step is actually presenting the final piece. And then at the very end of the semester you turn in a paper like about further work or what you would do different. (Student interview, Course C, Learning Plan)

What they do in these design reviews, everybody's required to give a presentation, everyone's required to give feedback and the students have two ways of giving feedback: you can either do it in writing or you can do it verbally. And I tell them, it's not like you have to ask some kind of ground-breaking question to your colleague. But you have to ask something that demonstrates that you've been cerebral through this whole presentation right? Because I'm trying to teach them to actually engage and to really be a part of this. (Instructor interview, Course E, Learning Plan)

\section{Seeing Relationships}

No examples were observed in the data for this indicator.

\section{Desiring to Resolve Ambiguity}

I think that's a goal, I mean, how do you create a situation where rather than being purely theoretical or being based solely on explicit knowledge, you create some tacit knowledge and understanding of situations so that when they find themselves having to work with people they don't understand completely or where they are coming from and they have to negotiate basically they have some strategies and some ability to resolve those things and continue work. (Instructor interview, Course A, Desired Results)

An organized way of thinking and attacking new problems and if and when you are feeling uncomfortable you can really get organized enough to really solve the problem. (Instructor interview, Course C, Desired Results)

Yeah, I point to ways of doing simple calculations that would tell them if that's a good way to approach the problem, or not. Like scaling you know if you're that's my favorite thing. You have a problem, you have no clue what the solution is, but you just start thinking about how the physical process involved, listing all the parameters and then trying to come up with simple scaling laws that helps guide you to the solution. (Instructor interview, Course C, Learning Plan) 


\section{Openness and Courage to Explore Ideas \\ Problem Sensitivity}

We say, "Well okay, that's what you can work on," and then there's the high value problem. So what's the highest value problem for your team? And that might not be the most complex thing, it might not be the most beneficial thing. (Instructor interview, Course A, Desired Results)

I want them to be able to walk into a situation that involves people from all walks of life, not just engineers or business or artists or designers or whatever, and address a problem that is being put on the table starting from "Is this a problem? Why is this a problem?" and proceeding from there all the way to finding solutions, or alternative designs, concepts, that will work. (Instructor interview, Course B, Desired Results)

If the students walk away actually having learned something about how to actually formulate a problem, digest it into observable enough pieces so there's sort of continued progression on the project. (Instructor interview, Course F, Desired Results)

So all of the games I'm building are for [Name] Hospital. And that's why when I gave the introduction and sent the proposals, some of the people there were from [the hospital]. And they came over just 'cause they know better the different disability levels. (Instructor interview, Course D, Learning Plan)

The reverse brainstorming, you aren't always given a problem to solve. A lot of engineers are given problems and are expected to solve them, but in a truly creative and innovative process you would have to be coming up with a problem yourself and identifying high-value problems. (Student 2 interview, Course A, Learning Plan)

\section{Aesthetic Sensitivity}

They really need to have, I mean, generally students who do have some kind of rightbrain skills in terms of artistic skills that they know how to bring art to this game, rather than, here's an outline of Illinois, what's the state capitol? That they can bring something interesting- artistically interesting - whether background, foreground, other things ... and you can tell looking at these where the students have had you know some strong graphics background. (Instructor interview, Course D)

Design Criteria: How was your team able to synthesize the form, function and behavior of the surface? (Syllabus, Course A, Assessment Evidence)

\section{Fantasy and Imagination}

They wanted to teach us the value of iteration in building. For example [Name] would always say, he would always encourage us to play, and I don't think he really meant play like run and throw a ball around, I think he really meant find it fun to do whatever you're doing and toy around with whatever this is and don't be afraid to drop it and then try something else. (Student 2 interview, Course A, Desired Results)

By creating the opportunity, funding the projects, you know, get leverage in them access to the facilities, you know? This being a special type of experience and there's also a skunk works phenomena, you know. Then I think it helps them invest to a certain point. (Instructor interview, Course A, Learning Plan) 
It's a huge amount of buy-in. They have to see this as a two way street. It's not something that I'm imparting on them, they are part of that creation. So if they are creating their class and they're creating their project, then they're much more likely to be engaged. (Instructor interview, Course E, Learning Plan)

\section{Tolerance for Ambiguity}

We have a framework. We have negotiated a territory, but part of the thing is coming at this in such a way that we do not know the outcome. One of the things we do, they are being given puzzles. Someone already knows the answer; whereas what we are doing is we are giving them problems we don't know the answer. We are in the exact same boat or position that they are and we're upfront about that. One of the most powerful things you can say is "I don't know" because that gives you a position from which to begin a process of inquiry. (Instructor interview, Course A, Desired Results)

I'm more than comfortable to not have the answer and I think that's where students start recognizing a change in focus. It's nice when the answers are always in the back of the book, like there's always an answer and the faculty is the oracle. And it's interesting when the data doesn't necessarily match up with what the book value is. And the question is why doesn't it match up? And I've heard lots of rationale as a reasoning, most of it not right but, you know, it's surprising to sort of recognize the students are immediately uncomfortable when suddenly the book isn't necessarily all telling. We don't necessarily want to tell people it's not worth measuring anything because it's too hard to do it. I mean it's not necessarily what we want people to walk away with. But we would like people, our graduates, to sort of walk away with a comprehensive appreciation for what we're actually trying to do, how we're actually trying to measure something. They start seeing inklings of the fact that one of the reasons that engineers are being hired effectively as valued higher organizations is solving problems that aren't known. (Instructor interview, Course F, Desired Results)

I want them to feel uncomfortable, and if they are feeling very uncomfortable it's because they are doing something new and I think exploring new areas that they would not do outside this course. (Instructor interview, Course C, Desired Results)

So in a sense, they have to try and work out what it is they are doing within a very ambiguous and fluid set of constraints. You know, I mean, yes, that is creative. (Instructor interview, Course A, Learning Plan)

We honestly don't know what's going to work in the end ... and really testing is what helps us design what we need to design because we don't know until we do it. (Student interview, Course C, Learning Plan)

\section{Intuition}

They can solve a problem that they never thought they would be able to and then they get the confidence to go out in the industry and attack a new problem and come up with a different solution. (Instructor interview, Course C, Desired Results)

I would like them to be able to feel like they're equipped to be able to develop their own test as necessary. I would like them to be comfortable with working in the lab group environment, such that when presented with some other open-ended question 
they know what kind of tools may be available for them to be sort of ultimate tests to probe, perturb, their system in some sort of other effective way (Interview, Course F, Desired Results)

\section{Integration of Dichotomies of Opposites}

No examples were observed in the data for this indicator.

\section{Listening to One's Inner Voice}

\section{Metacognition}

I have a main creativity lecture mostly to get them to think about it in a conscious way. (Instructor interview, Course B, Desired Results)

I think it's just that relentless accumulation of requirements: "You have to do this, you have to do this, you have to do this. Yes I understand you are not going to do it perfectly, but you have to do it." And just not leaving any way out for them to say no I cannot do it, except if they can argue successfully that they don't need to do it. (Instructor interview, Course B, Learning Plan)

And then at the very end of the semester you turn in a paper like about further work or what you would do different. (Student interview, Course C, Learning Plan)

Each team member is required to maintain an online course blog describing the intent and progression of their work. (Syllabus, Course A, Learning Plan)

I do think that we do draw comparisons between whether something is potentially easier to do or something that's potentially more robust or more accurate but we don't necessarily - we do sort of spend a lot of time thinking about where our bias is in the sort of measurements that we actually do generate. (Instructor interview, Course F, Learning Plan)

Reflection. Also, I mean, so statements like the engineer who's going "Why do I need an engineering degree?" We look for that kind of stuff. (Instructor interview, Course A, Assessment Evidence) 